\title{
Learning Styles: Learning that Empowers Students?
}

Tofi Rahal

Despite much disagreement, educators and psychologists agree that different students learn differently. Learning differences come under many labels, such as 'learning styles', 'thinking styles', 'personality types' or 'multiple intelligences'. This paper supports the use of learning style models as a theoretical framework for quality educational development in the Arab Gulf Countries. It will (a) briefly explore various learning styles models, with primary focus on the Dunn \& Dunn model and its assessment instruments; (b) review key research conducted internationally, as well as locally at Zayed University; (c) examine the benefits of using multimodal and multisensory instructional packages in various disciplines; (d) consider divergent ideas and thoughts on the value of introducing learning style based education. 


\section{INTRODUCTION}

Learning styles are characteristics of how students prefer to learn. They draw their origin from biological and experiential conditions that make each student unique in the way $\mathrm{s} /$ he learns. Many disadvantaged students who perform poorly in a conventional setting may experience a mismatch between their learning styles and the teaching styles of their instructors; for example tactile/kinesthetic learners may not respond well to learning by listening or by reading, while global learners might be turned off by a strict analyticsequential, step-by-step presentation. Furthermore, mismatched instruction might subject students to certain academic stress. Studies have demonstrated that the use of instruction that is congruent with student learning styles can improve academic achievement as compared with mismatched instruction. As a result, various learning styles models have emerged over the past 35 years. The idea that students learn, study, and work differently has become a prominent educational theme. However, determining the exact nature of individual learning styles and the best approach to advance learning is still a controversial and complex venture.

Higher education institutions are under pressure to shift toward educational practices that improve student autonomy and lifelong education. An increasing number of research activities acknowledge the limitations of a traditional teacher-centered approach in delivering a holistic education that meets students' diverse multi-level abilities to become self-efficient and lifelong learners (Freire, 1973; Terenzini \& Pascarella, 1994; Palmer, 1998; Komives \& Woodard, 2003). Learning is a complex endeavor, and how we learn, think and decide is still a mystery. Learning may mean different things to different people, and today the debate continues on the best ways to improve the process of teaching and learning is still underway. At the heart of the debate are key questions such as:

- How do people learn? Do all people learn in the same way?

- Can those entrusted with students' education change the ways their students learn?

- What kind of learning do current educational systems seem to promote the most? What types of students seem to be benefiting/ suffering the most from current practices?

- Is learning a function of genetic predisposition or life experiences?

- What are the limitations that affect our learning?

- Can students have a say in what and how they learn?

As educators and psychologists struggle to answer these and other related questions, most of them accept in some sense the idea that students learn differently, and that they are better served when curriculum designs and instructional methods support differentiated learning styles and abilities and raise motivation levels. In the past three decades, numerous authors have recognized the need to assess and identify students' learning styles as a basis to improving learning (Dunn et al., 1984; Entwistle \& Hanley, 1979; Gregorc \& Butler, 1984; Keefe \& Ferrell, 1990; Kolb, 1984). Educational institutions across the world are more aware of learning styles theory and learning styles assessment; however, Dunn et al. (1997) have found diffusion is rather slow due to certain features of teaching in higher education:

1. University teachers tend to assume that college students know how to study. Without that ability, how could they have succeeded well enough in high school to warrant admission into college?

2. Although college and university professors have experimented with instructional approaches such as case studies, cooperative learning, independent study or role play, for the most part these strategies have proven no more effective than lectures or readings - particularly with at-risk students (Boyle \& Dunn, 1998; Jones \& Watson, 1991). The main reason is that these strategies have been used without paying close attention to how students learn.

3. Teachers' instructional styles often do not match students' learning styles. Teachers tend to use instructional styles that are congruent with the way they learn; Whitefield (1995) has noted that "the more traditional methods of teaching are in the analytic part..." since "most teachers are Analytical in nature (about $80 \%$ ). Yet only $45 \%$ of students are Analytical in the early part of high school".

4. Traditional instruction tends to focus on auditory and analytical modalities and pays little attention to other modalities. Reiff (1992) found that a majority of underachieving school students school are kinesthetic or tactual learners.

In the Arab world, attempts to shift to learning- and learner-based education are likely hindered by culture, language, politics, economy, teaching practices and student characteristics. Some studies, mainly by Western researchers, have found Arab students to be dependent, indecisive, emotionally nonverbal, and often survival-oriented rather than insight-oriented (Bahoora, 1996; Arden-Close, 1999; Nassar-McMillan, 2003). These characteristics would constrain individuals from having a clear future perspective, vision, and planning. They also depress motivation level for students. According to McCombs \& Whisler (1997), in general students' difficulties in learning are related to learner characteristics and/or poor teaching practices.

\section{LEARNING STYLES MODELS}

There is a wide variety of learning styles models available. To simplify the comparison, Riding and Rayner (1998) propose four distinct descriptive categories: 
- Information Processing Based Models

- Social Interaction Based Models

- Cognitive and Personality Based Models

- Instructional and Environmental Based Preferences

An example of an information processing based model is the Kolb Experientia Model of Learning Styles. Kolb (1984) proposed two dimensions of perceptual and cognitive style, which can be combined to produce four general types of learner:

Accomodators combine Concrete Experience (CE) with Active Experimentation (AE), and are mainly concerned with aspects of the physical world.

Divergers combine Concrete Experience (CE) with Reflective Observation (RO), and focus on the social aspects of the world in addition to the physical aspects.

Convergers combine Abstract Conceptualization (AC) and Active Experimentation ( $A E)$, and are usually concerned with concepts and their applications.

Assimilators combine Abstract Conceptualization (AC) and Reflective Observation (RO), and are mainly concerned with reflecting on the meaning of concepts in different contexts with less regard to testing them out.

According to Kolb, students' experiences have the potential to change their learning preferences. For instance, science students become more analytical and less creative, while arts students become more creative and less analytical, thus widening the gap in learning preferences between students of different majors.

Social interaction based models of learning styles focus primarily on study as the basis to their approach. Entwistle (1981) developed the Approaches to Study Inventory (ASI) with scaled measures on three approaches to studying: deep, surface, and strategic. Similarly, Biggs $(1978,1987)$ proposed the Study Process Questionnaire (SPQ) for the measurement of motivationa and instrumental traits, again scaled on varying degrees of preferences for deep, surface and achieving levels. According to Duff (2004), learners taking Deep Learning approach look for meaning in what they are learning and enjoy the learning activity; make connections to previous learning; use logic, reasoning, and evidence well; and examine critically what they have learned and are learning. Learners taking a Surface approach rely primarily on memorization; have difficulty using logic, reasoning, and evidence; make fewer connections to previous learning; and have difficulty studying. Strategic learners can organize their studying routines, manage their time, and learn what is expected to achieve the highest grade possible.

Cognitive/personality based models assume that cognitive styles are closely related to personality traits, and that the way we perceive our environment determines the way we act upon our environment. Prominent work in this area includes the concept of field-independence, summarized by Keefe (1979) as follows: "The degree of our field-independence determines how learners perceive, interact with, and respond to the learning environment". Generally speaking, field-independent learners do much better in individualized learning situations, such as distance learning, than do field-dependent learners.

Howard Gardner's Multiple Intelligences Theory (1983) identified eight types of personal 'intelligence' which schools need to attend to, and his model has become very popular among educators and school teachers. The two ways of thinking most valued by conventional educational systems are Logical-Mathematical and Linguistic intelligences. These are only two of eight intelligences described by Gardner based on biological and cultural research. The others are defined as Spatial, Musical, Bodily-kinesthetic, Interpersonal, Intrapersonal, and Naturalist intelligences.

Myers-Briggs Personality Types Indicator, known as MBTI, identifies an individual personality profile as one of sixteen types, based on the following four dimensions:

- $\quad$ Orientation to life (Extrovert vs. Introvert).

- Perception of the outside world (Sensing vs. iNtuitive)

- Making decisions (Thinking vs. Feeling).

- Attitude toward the outside world (Judgment vs. Perception).

For instance, a personality type of "ISTJ" has different characteristics from an "INFP" personality type.

Variations of widely used instruction based models are known as VAK (visual, auditory, kinesthetic/tactile) and VARK (with R for read/write)

- Visual learners prefer to learn by viewing pictures, graph and maps.

- Auditory learners prefer to learn from verbal lectures and conversation.

- Kinesthetic learners prefer to learn through experiments, lab work and other practical activities.

- $\quad$ Read/Write learners prefer to learn through reading written materials and making detailed written notes or lists.

This paper will use an extended instructional/environmental based model of learning styles developed by Dunn \& Dunn. This approach aims at giving the user control over the leaning process. It provides both teachers and students with a reasonably simples model to inform appropriate choices about learning and teaching styles. The following advantages of the Dunn \& Dunn Model are most evident:

- Comprehensive: assessing six different aspects of learning styles, 
thus incorporating elements of other models.

- Supported by a well-equipped team of experts.

- Suited to diverse cultures, languages, and conditions.

- Validity and reliability are well supported by research.

- The model and its results are easy to understand and interpret for students, faculty and parents.

- Students can self-administer, self-score, and self-interpret the results of the online survey.

In short, this model is comprehensive and supported by research, with direct applications for the classroom. It can be used on its own or as a base for the pursuit of more specialized models.

\section{THE DUNN \& DUNN LEARNING STYLE MODEL}

Dunn \& Dunn (1993) define learning style as "the way in which individuals begin to concentrate on, process, internalize, and retain new and difficult information" (p. 2). The Dunns' model of learning style is based on the following assumptions:

- Most individuals are able to learn.

- Individual learning preferences exist and can be measured reliably.

- Everyone has a set of learning styles at different strengths. Different people have very different sets of learning styles.

- Students score higher in an environment that promotes matched rather than mismatched instruction.

- Most teachers can be trained to use learning styles to develop suitable instruction.

- Many students can learn to capitalize on their learning style strengths to tackle a new or difficult academic situation.

Dunn et al. (1995) provide an extensive analysis of 42 research studies using the Dunn and Dunn model that validate the model. The new refined mode developed by Rundle and Dunn adds an assessment validation component: asking the questions several times in different ways. Dunn et al. (1995) also present research that shows enhanced student performance in courses when faculty match learning activities to student learning style preferences as determined by the survey.

In 1996, Susan Rundle began collaboration with Rita Dunn on the development of Building Excellence: The Learning Individual ${ }^{\circledR}$ Inventor $\left(\mathrm{BE}^{\circledR}\right)$ (C1996-2005). The new BE, which was developed in 2005 (Rundle \& Dunn, 2005) is based on the Dunn and Dunn model, and assesses students on 28 elements organized into six strands: Perceptual, Physiological, Environmental, Emotional, Sociological, and Psychological. The six strands and their respective elements are shown in Figure 2 below, and Figure 3 provides a brief description of each element of the model.

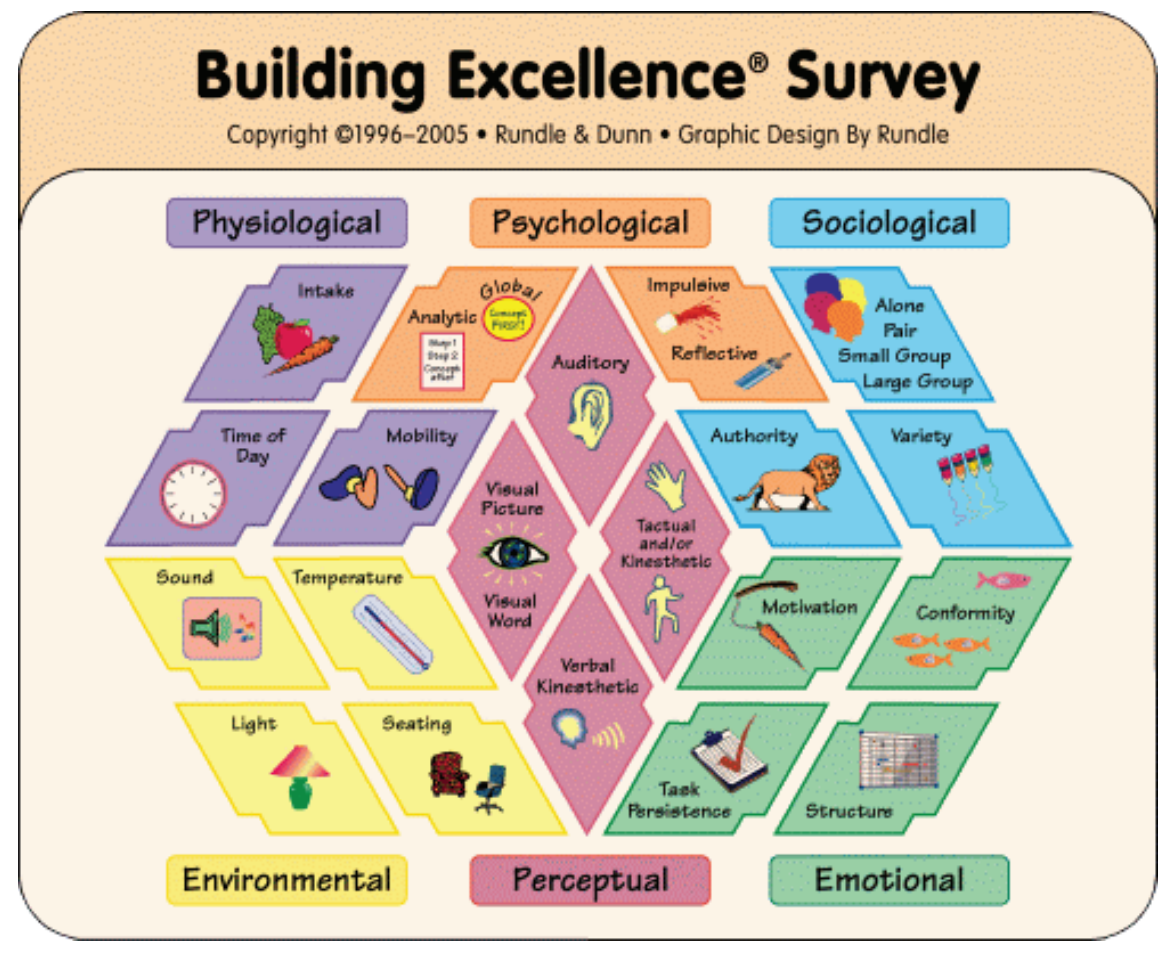

Figure 2: Learning styles model underlying the $B E$ survey

Rundle and Dunn's $B E$ is a commercially available questionnaire that offers a set of 116 questions covering all six categories and their respective elements for US\$5 per survey. Each of the above elements is assessed at a value from 0 to 100 , with $0-20$ or $80-100$ representing a strong preference in one direction or the other, 40-60 representing a balanced preference for the two ends, and 20-40 or 60-80 reflecting a moderate preference for the one pole or the other. Based on her responses, each learner is thus assigned to one of 5 percentiles on each of the above elements. For instance when assessing a student's preference for working alone, a student might display a strong tendency to work alone, a moderate tendency to work alone, a balanced tendency to work alone/with others, a moderate tendency to work with others, or a strong tendency to work with others. Students and faculty can self-administer, selfscore, and self-interpret the BE results if purchased online. 


\begin{tabular}{|c|c|c|}
\hline Category & Elements & Description \\
\hline \multirow{6}{*}{ 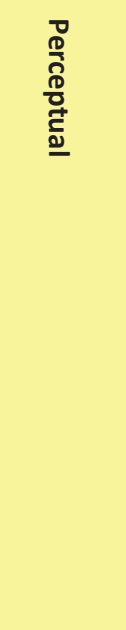 } & Auditory & $\begin{array}{l}\text { Whether you learn better by listening and } \\
\text { hearing. }\end{array}$ \\
\hline & Visual Picture & $\begin{array}{l}\text { Whether you learn better by using your mind's eye } \\
\text { or seeing illustrations and graphs. }\end{array}$ \\
\hline & Visual Word & $\begin{array}{l}\text { Whether you prefer seeing words instead of } \\
\text { pictures; i.e. written directions instead of map }\end{array}$ \\
\hline & Tactual & $\begin{array}{l}\text { Whether you prefer to learn by using physical } \\
\text { sensory input }\end{array}$ \\
\hline & Kinesthetic & $\begin{array}{l}\text { Whether you prefer to learn by moving and acting } \\
\text { (hands on). }\end{array}$ \\
\hline & Verbal Kinesthetic & $\begin{array}{l}\text { Whether you prefer to express yourself to other } \\
\text { people or aloud to yourself. }\end{array}$ \\
\hline \multirow[t]{2}{*}{ 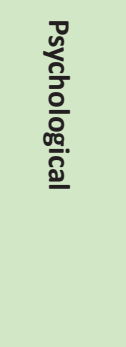 } & Analytic/Global & $\begin{array}{l}\text { Whether you prefer to build up your knowledge } \\
\text { piecemeal from facts and figures (analytical), or } \\
\text { you prefer to get the Big Picture first and slot in the } \\
\text { detail afterwards (Global) }\end{array}$ \\
\hline & Reflective/Impulsive & $\begin{array}{l}\text { Whether you prefer to think about and weigh } \\
\text { all your options before making a final decision } \\
\text { (reflective), or you hastily take your decision } \\
\text { (Impulsive) }\end{array}$ \\
\hline \multirow{4}{*}{ 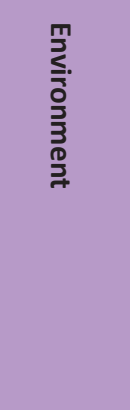 } & Sound & $\begin{array}{l}\text { Whether you prefer to have sound while working } \\
\text { or silence. }\end{array}$ \\
\hline & Light & $\begin{array}{l}\text { The best amount of light you prefer when } \\
\text { working. }\end{array}$ \\
\hline & Temperature & $\begin{array}{l}\text { Whether you prefer to work in a warm or cool } \\
\text { temperature. }\end{array}$ \\
\hline & Seating & $\begin{array}{l}\text { Whether you prefer to study while sitting at a desk } \\
\text { or on the floor with cushions, or on a sofa or bed. }\end{array}$ \\
\hline
\end{tabular}

\begin{tabular}{|c|c|c|}
\hline \multirow{6}{*}{ 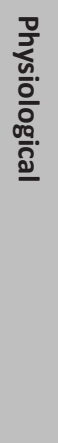 } & Early Morning & Whether you are more productive early morning \\
\hline & $\begin{array}{l}\text { Late Morning/Early } \\
\text { Afternoon }\end{array}$ & $\begin{array}{l}\text { Whether you are more productive late morning/ } \\
\text { early afternoon }\end{array}$ \\
\hline & Late Afternoon & Whether you are more productive late afternoon \\
\hline & Evening & Whether you are more productive in the evening \\
\hline & Intake & Whether you prefer to take snacks while working. \\
\hline & Mobility & Whether you prefer to move while studying \\
\hline \multirow{4}{*}{ 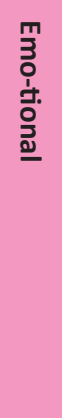 } & Motivation & How much inner drive you have \\
\hline & Task Persistence & $\begin{array}{l}\text { Whether you prefer to stick and complete a task } \\
\text { before you go to another. }\end{array}$ \\
\hline & Conformity & $\begin{array}{l}\text { How much influence other people opinions has } \\
\text { on you or whether you prefer to take the risk and } \\
\text { challenge. }\end{array}$ \\
\hline & Structure & $\begin{array}{l}\text { Whether or not you prefer to have precise } \\
\text { information on how to perform a task. }\end{array}$ \\
\hline \multirow{6}{*}{ 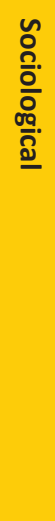 } & Alone & Whether you prefer to work alone. \\
\hline & Pair & Whether you prefer to work with a friend \\
\hline & Small Group & $\begin{array}{l}\text { Whether you prefer to work as a part of a small } \\
\text { group }\end{array}$ \\
\hline & Large Group & $\begin{array}{l}\text { Whether you prefer to work as a part of a Large } \\
\text { group }\end{array}$ \\
\hline & Authority & $\begin{array}{l}\text { Whether you prefer to work with an adult or } \\
\text { expert present }\end{array}$ \\
\hline & Variety & Whether you prefer a variety of the above. \\
\hline
\end{tabular}

Figure 3: Dimensions of the Dunn \& Dunn model.

\section{LEARNING STYLES RESEARCH INITIATIVES IN THE UAE}

In April-May 2008, 726 students in the General Education and Major programs at Zayed University (ZU) were assessed on various Dunn and Dunn learning styles elements. Data on the perceptual and psychological modalities was analyzed and presented by Rahal and Palfreyman (2009). A summary of the overall trends in these two areas is given below. 


\section{Perceptual learning style profile}

Figure 4 shows Verbal preference to be the most favoured style: $27.6 \%$ showed a preference for this style (note that this study includes only female informants; this finding may be related to a tendency for females to learn verbally, cf. Northwestern University, 2008). Students coming from private schools tended to favour this style $(54.5 \%)$ more than those coming from government schools (39.8\%). This could reflect a greater opportunity/ incentive in private schools for students to express their learning verbally.

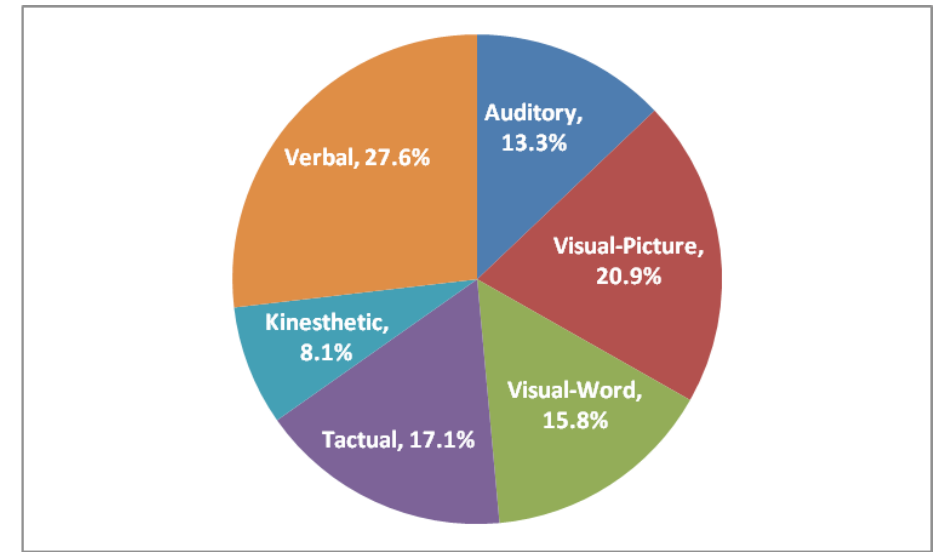

Figure 4: Percentage of students for each perceptual preference.

The second most favoured perceptual style is Visual-Picture, followed by Tactual. The least favoured style, by this measure, is Kinesthetic, perhaps reflecting cultural restrictions on girls and women using their whole body in activities. The students most favouring a tactual style are those from government schools living in less urbanized areas (Ajman, Dubai outside the city, Abu Dhabi off the central island); it seems likely that such students would assist more in household work and taking care of siblings. Higher-GPA students tend to have lower tactual and kinesthetic preference than lowerGPA students. This is in agreement with research findings in the Western world, reflecting the lack of attention to kinesthetic learning in most educational systems.

\section{Psychological learning style profile}

According to Figure 5 below, the majority of students appear to take a balanced preference regarding a Reflective or Impulsive approach to tasks, but more than a third of them are assessed as taking a Reflective approach, while just $6.7 \%$ of students appear to favour an Impulsive approach. A Reflective approach to learning may be related to a local cultural expectation for people (and especially women) to pause before speaking in public contexts.

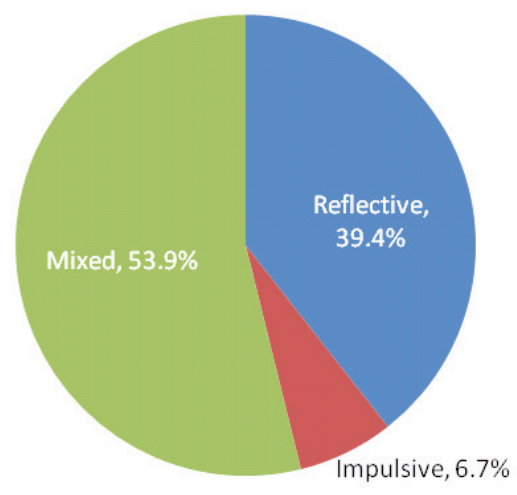

Figure 5: Students Distribution: Reflective vs. Impulsive.

On the Analytic/Global dimension, Figure 6 shows again that the majority of students are mixed in their responses; a quarter of them take an Analytic approach (perhaps reflecting a Left-brain bias linked also to the preference for a Verbal style - see above); very few appear to favour a Global approach. As with the Reflective/Impulsive dimension, this distribution is probably indicative of the learning profile assessed and supported in university contexts.

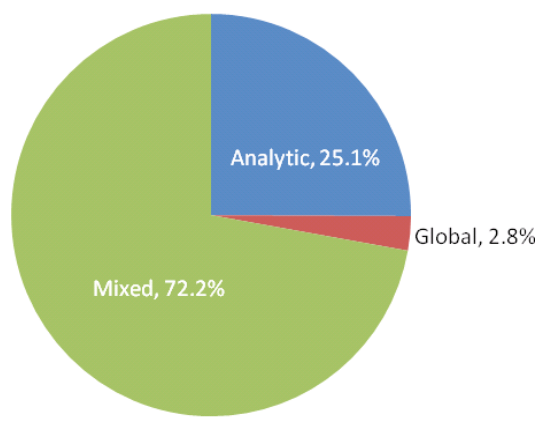

Figure 6: Students' preferences: Analytic vs. Global.

\section{Gender variation}

The relationship between gender and learning styles has been well documented (Dunn \& Griggs, 2007; Honigsfeld \& Dunn, 2003; Reese \& Dunn, 2007-2008). Dunn and Honigsfeld (2009) concluded that "many males 
and females learn differently from each other". Males tend to be more kinesthetic/tactual and visual, and need more mobility in a more informal environment, while females are usually more auditory and more internally motivated. They are more adapted than males to sitting passively in a conventional classroom; active learning strategies are believed to be more appealing to males.

In 2008 a variation of the VARK survey was administered to 170 student from grades 10 - 12 on Delma Island, UAE. 72 students from the boys schoo and 98 students from the girls school participated in this research. Hard copies of the survey in Arabic were delivered instead of the online version. The results (see Figure 7) seem to support the idea that males tend to be more kinesthetic and less auditory than females. It is however worth noting that female students on Delma Island, a relatively isolated and rural area, displayed higher kinesthetic and tactual preferences than females at ZU. This is in agreement with the assumption made earlier that females in less urbanized areas seem to use movement and touch in their learning more than those in urban areas, such as in Dubai or Abu Dhabi city.

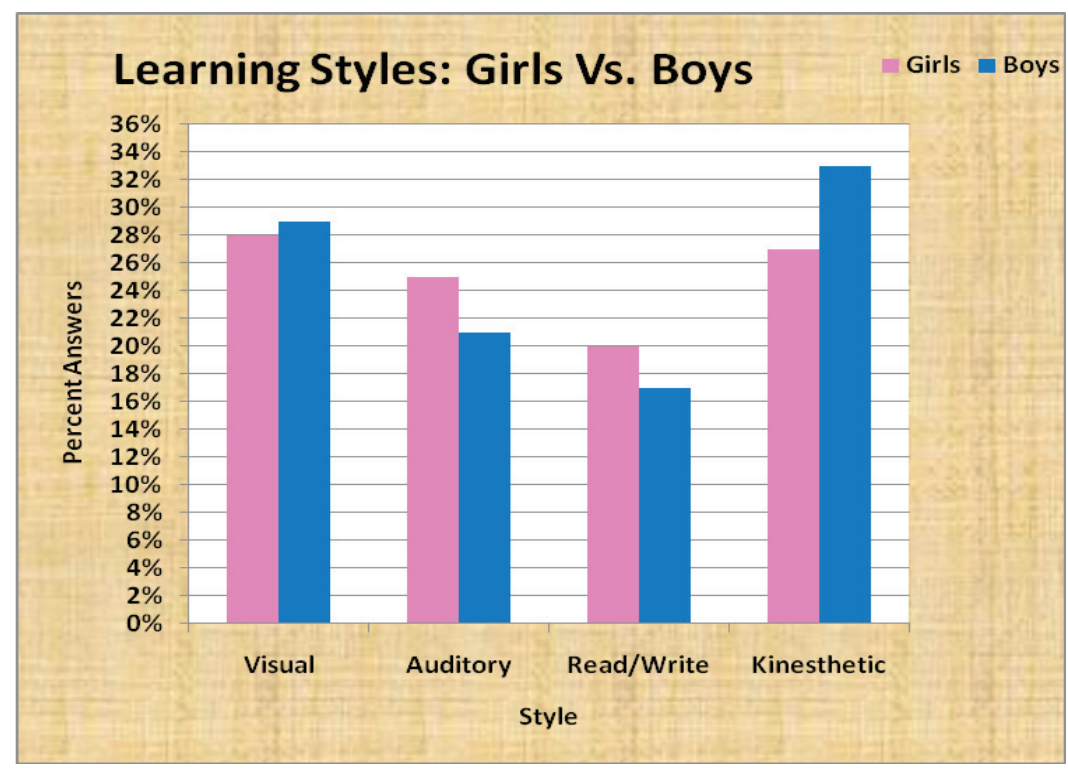

Figure 7: Learning preferences of girls vs. boys on Delma Island.

\section{Effect of different Learning Style Strategies on Performance}

One of the key premises of a learning styles based approach to education is that instructional strategies and resources that accommodate student learning styles improve their academic performance, motivation and attitude toward schooling. Cohorts of different learning styles patterns respond differently to different instructional strategies. Two important individualized instructional strategies Programmed Learning Sequences (PLS) and Contract Activity Packages (CAP), were investigated with reference to the learning styles of 60 students taking an introductory Environmental Science course at Zayed University.

PLS is an instructional strategy that presents information in a series of simple sequential learning frames: "learning chunks" that are immediately reinforced. PLS works well with mainly analytic students whose learning style profile indicates strong preferences in the following:

- Structure

- Persistence

- Visual Input

- Tactile Stimulation

CAP is another individualized instructional strategy that guides students through an independent learning experience and activities that meet the same learning objectives as PLS, but offers learners more opportunity for choice as to how they work with the resources and activities provided. It works well with students whose learning style profile indicates the following characteristics:

- Strong on independence and choices.

- High on motivation and persistence.

- Low on conformity, authority, and responsibility

In Fall 2009, an Environmental Science class of 60 students at ZU was given the $B E$ survey to determine their learning styles. The class was then randomly subdivided into 2 equal groups to work on specific learning objectives related to the topic of global warming. One group used the PLS strategy, while the other received materials based on the CAP strategy. Both groups were given the same pretest and then a posttest one week later.

A preliminary analysis of students' distribution regarding learning styles seems to show agreement with the distribution of the larger group, with verbal preferences being the most favoured and the kinesthetic preferences being the least favoured.

The mean scores for the pre- and post-tests for both PLS and CAP cohorts are displayed in Figure 8. 


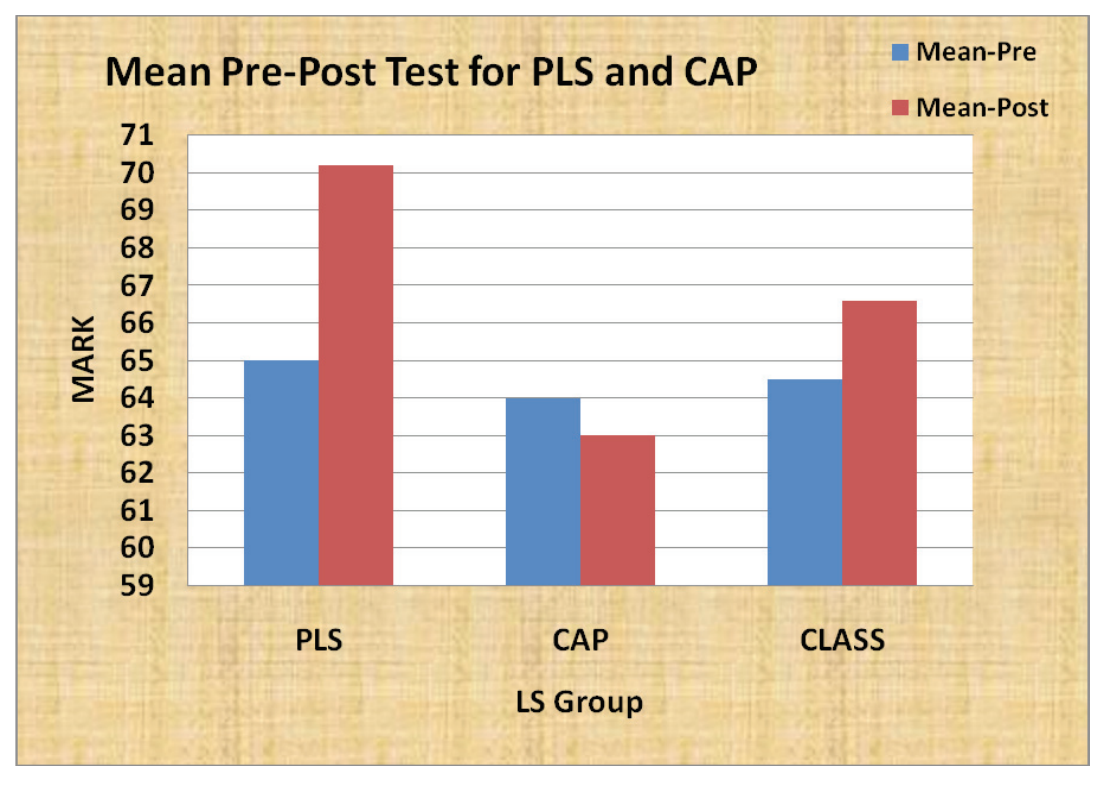

Figure 8: Mean pre- and post-test scores for PLS and CAP.

Note that both groups have similar mean score on the pretest. On the posttest, however, the PLS group seemed to have out-performed the CAP group. For the CAP cohort there was no significant difference between the mean scores of both tests. As a matter of fact, the score on the posttest even declined by 1 point. This might be an indication that students in this class, and possibly all Emirati students, prefer instruction that is structured in an analytic, sequential, and directed way. It might also indicate that information that is presented in small "learning chunks" is easier for students to process than in larger amounts. Presenting too much information at once might impede the learning process of some students (especially those who possess inadequate cognitive structure and general ability skills).

Both Behaviorism and Cognitivism support the practice of analyzing a task and breaking it down into manageable chunks whose acquisition is made easier in achieving the learning objectives (as in PLS). Constructivism, on the other hand, promotes a more open-ended learning experience, where the methods and results of learning are less easily measured and may not be the same for each learner.

\section{IS LEARNING STYLE BASED EDUCATION THE ANSWER?}

A recent article in the Chronicle of Higher Education (Glenn, 2009) reviews arguments by four psychologists against the validity of many of the research studies on learning styles. The contributors concluded that "matching teaching style to learning style may not help students", and indeed that trying to do the matching might be "a waste of time and effort". Readers can refer to this article and related comments for a quick review of the pros and cons of learning styles. However, a few remarks regarding this article and other literature that doubt the merits of learning styles are in order.

Firstly, let me agree with the authors of the article regarding the mediocre quality of some research in education. This is basically due to lack of solid scientific research programs in many educational departments, which can result in research with questionable findings that cause mistrust from scientists and psychologists. However, it is important to point out that, unlike other fields, education is a complex and dynamic human undertaking. How the brain works is still a mystery, and ideas and daily human interactions evolve from minute to minute in daily life. Such emergent interactions do not wait for research or researchers to tell us what to do: it often requires immediate attention from teachers to ease evident student distress or to clarify a sudden confusion.

Secondly, I would like to support Susan Rundle's comment in the same article: that learning styles is not only about matching instruction, it is about teachers knowing students better, knowing their teaching styles better, and reflecting on their daily practices: "What we do try to get professors to do, and where we've been successful, is to become aware of their own learning style and how that affects the way they teach. What are some things that they can do in the classroom other than just lecturing?" More important, learning styles is about students knowing and understanding themselves better, and then taking charge of their own study and learning, especially if we accept that only a part of what is taught in classroom is learned by students, as shown in Figure 9, which illustrates the disjunction between what is taught (on the left) and what is learned (on the right):

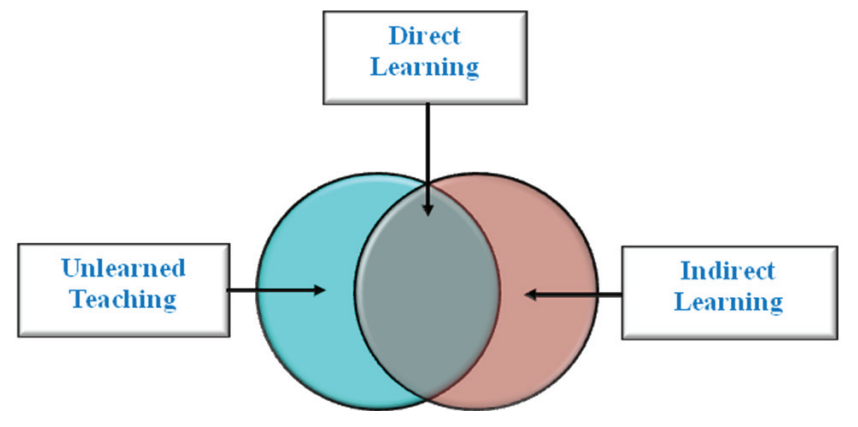

Figure 9: Teaching and learning.

This diagram shows that learning does not necessarily come from formal teaching, e.g. in the classroom. One of our responsibilities as educators 
and teachers is to find ways to engage learners both inside and outside the classroom. Learning style based techniques provide us with opportunities to empower students to take charge of their own learning in both formal and informal settings.

Thirdly, the article clearly affirms one of the great values of using learning styles in education: teaching activities that respond to students learning styles bring "love and enjoyment" to their learning experience. This in itself is a very strong argument for learning styles. The joy for learning can definitely yield higher motivation levels and improve students' attitude toward schooling, which in the long run can improve long-life learning. Rahal and Palfreyman (2009) presented a model (see Figure 10) to show the importance of learning styles in improving motivation, which in turn can help student learn better even things which are outside their comfort zone of learning styles.

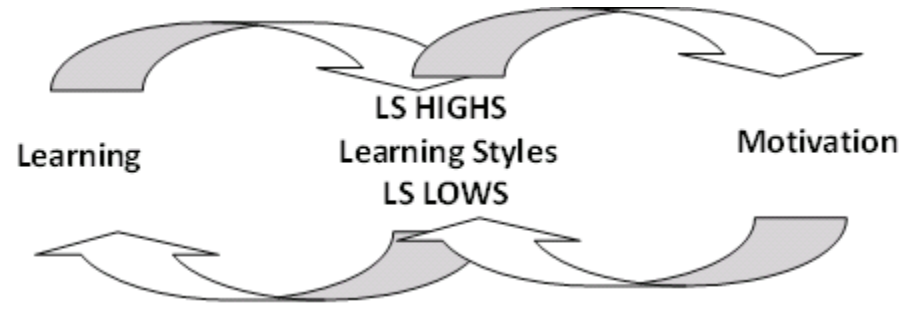

Figure 10: Learning styles and motivation.

This model suggests that learning which responds to student learning strengths (LS HIGHS) may yield higher motivation, which in turn can help students deal with learning styles that are low within their learning style profile (LS LOWS)

Finally, tracking and labeling students may have some drawbacks, but for a student to know that everyone has different learning strengths and that no learning style modality is better than another can help her/him feel secure and more comfortable in schooling. Ongoing research by Al-Alami, Rahal, and Al-Tareb is trying to investigate the relationship between learning styles, physiological, and psychological characteristics, and also to measure how the stress and anxiety level of students varies when they are subject to traditional lectures on a new and difficult subject. Would students respond differently to this type of lecture based on their learning styles characteristics?

\section{CONCLUSION}

Good educational practices must respect students' diverse needs and ways of learning. The concept of Learning Styles is instrumental in shifting from a traditional teacher-based educational system to a more effective learner- centered approach

Learning styles is not about demoralizing or threatening teachers or their ways of teaching, but a reminder that there exist new instructional choices to examine. By examining well established practices, teachers could develop more effective and possibly more motivating educational activities and experiences for both themselves and their students.

Learning styles is not about the labeling or demarcation of students, but an evident statement that we are all different and that when people find their potentials and strengths they become more motivated and empowered to take responsibility for their own learning. Learning styles assessment instruments must be flexible and adaptable to give students the opportunity to discuss and correct their own learning profiles.

Finally, learning style based education is a roadmap to help improve learning, primarily by helping students become more responsible for their own learning: it is not for everyone or all the time, and it is not a free ticket to success.

\section{REFERENCES}

Arden-Close C. (1999). Conflict of Learning Styles: University Science Lectures in the Sultanate of Oman: The student experience. Journal of Science Education and Technology, 8 (4), 323-332.

Bahoora, F. (1996). The cognitive and learning styles of Arabic students in American middle schools: the southeast Michigan experience. Doctoral Dissertation, UMI Anne Arbor, MI.

Biggs, J.B. (1978) Individual and group differences in study processes. British Journal of Educational Psychology, 48, 266-279.

Biggs, J.B. (1987). Study Process Questionnaire. Melbourne: Australian Council for Education Research.

Boyle, R., \& Dunn, R. (1998). Teaching law students through individual learning styles. Albany Law Review, 62 (1), 213-255.

Duff, A. (2004). Approaches to learning: The revised approaches to studying inventory. Active Learning in Higher Education, 5 (1), 56-72.

Dunn, R. \& Dunn, K. (1993). Teaching secondary students through their individual learning styles: Practical approaches for grades 7 - 12. Allyn \& Bacon: Boston.

Dunn, R., Dunn, K., \& Price, G. E. (1984). Learning style inventory. Lawrence, KS, USA: Price Systems.

Dunn, R., Given, B., Thomson, B.K. \& Brunner, C. (1997). The international 
learning-styles network: Where, who, when, what, where, why --and why not? National Forum of Applied Educational Research Journal, 11 (1), 26-29. Dunn, R. \& Griggs, S. A. (Eds). (2007). What if? Promising practices for improving education. Lanham, MD: Rowman \& Littlefield.

Dunn, R., Griggs, S.A., Olson, J., Beasley, M., \& Gorman, B.S. (1995). A metaanalytic validation of the Dunn and Dunn model of learning-style preferences. Journal of Educational Research, 88 (6), 353-362.

Entwistle, N.J. \& Hanley, M. (1979). Personality, cognitive style, and students' learning strategies. Higher Education Bulletin, 6 (1), 23-43.

Freire, P. (1973). Education for critical consciousness. New York: Continuum. Gardner, H. (1983). Frames of Mind: The Theory of Multiple Intelligences. New York: Basic Books.

Glenn, D. (2009). Matching teaching style to learning style may not help students. The Chronicle of Higher Education. Accessed 12 July, 2010 at

http://chronicle.com/article/Matching-Teaching-Style-to-/49497/

Gregorc, A.F. \& Butler, K.A. (1984) Learning is a matter of style. Vocational Education, 59 (3), 27-29.

Honigsfeld, A., \& Dunn, R. (2003). High school male and female learningstyle similarities and differences in diverse nations. Journal of Educational Research, 96, 195-206.

Jones, D.J. \& Watson, B.C. (1990). High-Risk Students and Higher Education: Future Trends. ASHE-ERIC Higher Education Report No. 3. George Washington University.

Keefe, J.W. (1979). Student Learning Styles: Diagnosing and Prescribing Programs. Reston, VA: National Association of Secondary School Principals.

Keefe, J.W. \& Ferrell, B.G. (1990) Developing a defensible learning style paradigm. Educational Leadership, 48 (2) pp. 57-61.

Kolb, D.A. (1984). Experiential Learning: Experience as the Source of Learning and Development. New Jersey: Prentice-Hall Inc.

Komives, S. R. \& Woodard, D.B. (2003). Student services. San Francisco, CA: Jossey-Bass.

McCombs, B. L. \& Whisler, J. S. (1997). Learner-centered classroom and schools: Strategies for increasing student motivation and achievement. NASSP Bulletin 81, 1-14.

Nassar-McMillan, S.C. (2003). Counseling considerations among Arab Americans. Journal of Counseling and Development, 81 (2), 150-59.

Northwestern University (2008). Boys' and girls' brains are different: gender differences in language appear biological. ScienceDaily. Accessed 12 July, 2010 at http://www.sciencedaily.com/releases/2008/03/080303120346.htm

Palmer, P. (1998). The courage to teach. San Francisco, CA: Jossey-Bass.

Rahal, T. \& Palfreyman, D. (2009). Assessing learning styles of students at Zayed University. Learning and Teaching in Higher Education: Gulf perspectives, 6(2). Accessed 12 July 2010 at http://www.zu.ac.ae/lthe/ the06_02 01_rahal.htm

Reese. V. \& Dunn R. (2007-2008). Learning-style preferences of a diverse freshman population in a large, private metropolitan university by gender and GPA. Journal of College Student Retention. Research, Theory \& Practice, $9(1), 95-112$.

Reiff, J. C. (1992). Learning styles. Washington, DC: National Education Association.

Riding, R. \& Rayner, S. (1998). Cognitive styles and learning strategies, London: David Fulton Publishers.

Terenzini, P., \& Pascarella, E. (1994). Living with myths: Undergraduate education in America. Change, 28, 28-32.

Whitefield, D. (1995). Learning styles - great minds don't think alike! In Summers, L. (Ed), A Focus on Learning, p271-275. Proceedings of the 4th Annual Teaching Learning Forum. 